\title{
Mechanisms of virus induced exacerbations of asthma
}

\author{
Jonathan M Corne, Stephen T Holgate
}

\begin{abstract}
Most work on the pathogenesis of asthma has studied airway inflammation using allergen challenge as a model. ${ }^{1}$ Although appropriate for our understanding of the underlying disease pathology, epidemiological studies have suggested that allergens are not common precipitants of asthma attacks ${ }^{23}$ and cohort studies have demonstrated the importance of upper respiratory tract (URT) viruses as probably the commonest cause of asthma exacerbations. ${ }^{45}$ Studying the effects of URT viruses should therefore help our understanding of the mechanisms underlying exacerbations of asthma and open up new avenues for therapeutic intervention. ${ }^{6}$ In this review we shall consider some of the effects of URT viral infection that are pertinent to their involvement in asthma and speculate on possible mechanisms of virus induced asthma exacerbations.
\end{abstract}

\section{Bronchial hyperresponsiveness}

Increases in bronchial hyperresponsiveness (BHR) have been found in both normal and asthmatic volunteers following infection with rhinovirus $^{78}$ and influenza $\mathrm{A},{ }^{9-13}$ and such increases can be prolonged, lasting, for example, for up to 15 days following infection with rhinovirus. ${ }^{14}$ It has also been reported that volunteers with atopic rhinitis who only show an early reaction to allergen challenge can develop both an early and late reaction following experimental rhinovirus infection. ${ }^{15}$ These increases in BHR may underlie the development of cough and other lower respiratory tract symptoms in normal individuals, and the increase in severity of asthma that occurs in asthmatic subjects following URT viral infection.

\section{Structural effects on the lower airways}

A number of animal models have been used to investigate the effect of URT viruses on lower airways morphology, though work in this area is limited by the few obvious examples of naturally occurring URT viral infections in animals. Two of the early studies described changes due to respiratory syncytial virus infection in the ferret ${ }^{16}$ and a poorly adapted strain of influenza in the mouse, ${ }^{17}$ both of which gave rise to a cold like illness without an associated pneumonia. Similar changes were seen in both with an early loss of ciliated and non-ciliated cells from the tracheal epithelium and the basal epithelial layer remaining intact. Regeneration of the epithelial layer began at five days and was complete by two weeks. Studies of chickens infected with viral laryngotracheitis ${ }^{18}$ and guinea pigs infected with parainfluenza 3 virus ${ }^{19}$ have demonstrated that virus induced epithelial disruption leads to significant increases in epithelial permeability and, as a consequence, an increase in permeability to allergens and an increase in allergen sensitisation. ${ }^{19}$ Other workers have studied in some detail the effects of parainfluenza type 1 (Sendai) virus infection in the rat. ${ }^{2021}$ In this model viral infection also leads to significant morphological changes to the airways with the early development of multifocal necrosis and sloughing of the epithelium lining the bronchi and bronchioles.

Work in humans has also demonstrated an effect of URT viruses on the epithelial integrity of the airways. In one study ${ }^{22}$ bronchoscopy and biopsy were performed on patients with uncomplicated influenza type A infection. Examination of their airways revealed extensive desquamation of epithelial cells to the level of the basement membrane and thickening, hyalinisation, and distortion of its structure. Other studies have focused on the effects of URT viral infection on ciliary function and have demonstrated delays in tracheobronchial clearance following influenza $\mathrm{A}$ infection ${ }^{23}$ and depressed nasal ciliary function following experimental rhinovirus infection. ${ }^{24}$

\section{$\beta$ adrenergic receptors}

An imbalance of $\beta$ adrenergic receptors has been proposed as a fundamental abnormality in asthma, ${ }^{25}$ and in vitro studies have demonstrated the ability of viruses to affect $\beta$ adrenoceptor function. In isolated smooth muscle taken from guinea pigs inoculated with influenza virus the protective effect of the $\beta_{2}$ agonist sulfonterol against ovalbumin induced contraction is reduced. ${ }^{26}$ The nature of this effect has been examined further. ${ }^{27}$ Mice infected with influenza A that developed infections confined to the URT were compared with those that developed infections of both the upper and lower respiratory tracts. Only in those animals with lower respiratory tract disease was receptor activity reduced with sig- 
nificant decreases in both isoprenaline and $\mathrm{NaF}$ stimulated adenylate cyclase activity.

Leucocytes express sympathetic $\beta$ adrenergic receptors and have proved a useful model of viral/receptor interaction. Granulocytes from asthmatic patients with URT infection show a decreased response to isoprenaline, ${ }^{28}$ suggesting that decreased $\beta$ adrenergic receptor sensitivity could contribute to virus induced attacks of asthma. It would not, however, explain the increase in BHR that follows URT viral infection since this phenomenon is not thought to be causally associated with changes in $\beta$ adrenergic receptor function.

\section{Cholinergic nerves}

Cholinergic overactivity could be a mechanism for virus induced increases in BHR since the bronchial hyperresponsiveness that develops following the common cold is blocked by atropine and reversed by isoprenaline. ${ }^{7}$ Evidence from animal models supports this hypothesis and suggests that it is overactivity of the efferent cholinergic nerves that is increased since, in guinea pigs, viral infection has been shown to augment the bronchoconstriction caused by electrical stimulation of the vagus nerve. ${ }^{29}$ Further work has suggested that viruses may act to increase cholinergic activity by causing dysfunction of the $\mathrm{M}_{2}$ muscarinic autoreceptor. Treatment with gallamine, an $\mathrm{M}_{2}$ muscarinic receptor blocker, leads to an increase in airway response to vagal stimulation in uninfected control rats but has much less of an effect in those infected with parainfluenza virus, suggesting that the viral infection has already disrupted the $\mathrm{M}_{2}$ receptor. ${ }^{30}$ This disruption would act to increase cholinergic responsiveness since the $\mathrm{M}_{2}$ receptor is an inhibitory neural autoreceptor, and its blockade would remove the negative feedback loop that limits acetylcholine release from cholinergic nerves.

There are a number of possible mechanisms by which virus infection could cause $\mathrm{M}_{2}$ receptor dysfunction. Viral neuraminidase has been shown to cleave sialic acid residues from $\mathrm{M}_{2}$ receptors, decreasing their affinity for agonists, and consistent with this are reports that neuraminidase inhibitors block the effect of parainfluenza 1 virus infection on receptor function. ${ }^{31}$ Another proposed mechanism, which may be more prominent in milder infections, is that receptor dysfunction is caused by inflammatory cell mediated damage. ${ }^{32}$ It is also possible that mechanisms independent of $\mathrm{M}_{2}$ receptors may contribute to cholinergic overactivity, ${ }^{33}$ and there are a number of candidate substances such as histamine, thromboxane, serotonin, and the tachykinins that can act as parasympathetic neuromodulators ${ }^{34}$ and could potentially be affected by virus infection. The most important of these, the tachykinins, are discussed below.

\section{Tachykinins}

One way in which viral infection could increase cholinergic responsiveness is through modulation of substance P. This tachykinin is con- tained in unmyelinated sensory airway nerves and can potentiate cholinergic neurotransmission, ${ }^{35}$ as well as directly cause neurogenic inflammation by inducing extravasation, neutrophil and eosinophil adhesion to vascular endothelium, submucosal gland secretion, cough, and bronchoconstriction. ${ }^{3637}$ Animal studies have suggested that modulation of substance $\mathrm{P}$ catabolism could be a mechanism by which viruses induce exacerbations of asthma. Parainfluenza 1 infection in guinea pigs has been shown to increase substance $P$ induced airway smooth muscle contraction ${ }^{38}$ and, in the rat, has been shown to amplify substance $P$ induced increases in airway blood flow. ${ }^{39}$ The effect on smooth muscle seems to be mediated through a decrease in the activity of neutral endopeptidase, an enzyme responsible for the catabolism of substance $\mathrm{P} .{ }^{40}$ Rats with a history of viral respiratory tract infection have decreased levels of tracheal neutral endopeptidase when compared with pathogen free rats ${ }^{41}$ and naturally acquired infections of the respiratory tract have been shown to decrease neutral endopeptidase activity in the rat trachea. ${ }^{41}$ Furthermore, phosphoramidon, an inhibitor of neutral endopeptidase, potentiates the increase in airway resistance that follows administration of substance $P$ in uninfected guinea pigs but does not do so in guinea pigs infected with Sendai virus, suggesting that neutral endopeptidase is already maximally or near maximally inhibited in virus infected animals. ${ }^{38}$ The potentiation of airway blood flow induced by viral infection may involve inhibition of angiotensin converting enzyme, which can also modulate substance $\mathrm{P}$ activity, as well as inhibition of neutral endopeptidase. ${ }^{39}$

\section{Cellular and cytokine changes in the airway}

Fibreoptic bronchoscopy has allowed examination of the cellular changes in the airway following both experimental rhinoviral infection $^{4243}$ and naturally acquired colds. ${ }^{44}$ In one study ${ }^{42}$ allergen provocation was undertaken in volunteers with atopic rhinitis before, during, and one month after experimental rhinovirus infection and differences in the early and late phase response were determined by performing bronchoalveolar lavage immediately and 48 hours after each allergen challenge. Important differences were noted in both the early and late phase responses during the acute phase of infection and one month after infection. The early phase reaction was associated with significantly higher levels of histamine in the bronchoalveolar lavage fluid when subjects were challenged during the acute phase of infection and one month after infection. The late phase response was also augmented. When bronchoalveolar lavage fluid at 48 hours following challenge was compared, levels of histamine and, more significantly, numbers of eosinophils were significantly higher when the procedure was performed during the acute phase and one month after rhinovirus infection than when performed before the 
infection. These changes did not occur in a control non-atopic group.

In another study ${ }^{43}$ asthmatic and non-asthmatic volunteers underwent bronchoscopy two weeks before (baseline) and four days (acute) and 6-10 weeks (convalescent) after challenge with human rhinovirus. Bronchial biopsy specimens demonstrated increases in the submucosal CD $4+\mathrm{T}$ cell, CD8 $+\mathrm{T}$ cell, and eosinophil counts during the acute phase of infection. CD $4+\mathrm{T}$ cell and CD8 $+\mathrm{T}$ cell counts had returned to baseline by convalescence, but eosinophil counts remained raised in the asthmatic group, in contrast to the non-asthmatic subjects whose counts returned to baseline levels. Interpretation of this study is limited since none of the asthmatic volunteers developed asthma symptoms or showed deterioration in spirometric parameters, although there was a significant increase in histamine responsiveness in the asthmatic group. It does, however, show the potential of rhinoviruses to cause airway recruitment of $\mathrm{T}$ cells and eosinophils, both important contributors to the inflammatory process, and highlights possible differences in the eosinophilic response between asthmatic and non-asthmatic subjects. It would have been interesting to take this work further by counting the numbers of CD25+ T cells and hence gain an appreciation of the effect of rhinovirus infection on activation of $\mathrm{T}$ cells - which is perhaps more relevant than absolute $\mathrm{T}$ cell numbers.

A more recent study ${ }^{44}$ has investigated the changes that occur in the lower airways following naturally acquired URT infections. This study found significantly increased numbers of eosinophils and CD8 $+\mathrm{T}$ lymphocytes in the bronchial mucosa of a group of atopic and nonatopic subjects following the development of common cold symptoms and a trend towards an increase in CD25+ T lymphocytes. Interestingly, when the changes in the atopic and non-atopic subjects were considered separately, the increase in CD8 $+\mathrm{T}$ lymphocytes only reached significance in the non-atopic group. One problem inherent in any study of this type is that the URT infections will be caused by various viruses, each of which may have different effects on the lower airways. In this study 20 subjects underwent bronchoscopy during the acute phase of URT symptoms, eight of whom were atopic and eight (two atopic) had a proven viral infection (two rhinovirus, three coronavirus, one parainfluenza, one respiratory syncytial virus, and one dual infection). Much larger numbers may be required to fully appreciate virus induced changes to the cellular profile of the airways, and certainly subgroup analysis is likely to underestimate any changes.

Virus induced cytokine changes have been studied using the nose as a model. We have studied the cytokine profile of nasal lavage fluid taken during naturally acquired common colds and compared the cytokine response of atopic and non-atopic volunteers. In agreement with previous studies ${ }^{45}{ }^{46}$ we have demonstrated increased levels of interleukin (IL)-6, IL-8, interferon (IFN) $-\gamma$, IL-1 $\beta$, and tumour necrosis factor (TNF)- $\alpha$ in the acute phase of a cold and have shown important differences between the atopic and non-atopic volunteers, ${ }^{47}$ with convalescent levels of IL- 6 and IL- $1 \beta$ remaining significantly higher in the atopic group than in the non-atopic individuals. This is in keeping with the biopsy studies described above in which differences in the response to rhinovirus infection between asthmatic and nonasthmatic subjects only became apparent 6-10 weeks after infection, possibly suggesting that infection promotes a series of inflammatory changes that can be limited in non-asthmatic individuals but not in those with asthma.

\section{Epithelium}

URT viruses will first interact with airway epithelium. Epithelial cells express the intercellular adhesion molecule ICAM-1 which is the receptor for the major group of rhinoviruses. ${ }^{4849}$ Recent work has shown that rhinoviruses have the ability to upregulate surface ICAM-1 expression and cellular mRNA in cultures of pulmonary epithelial cells and can also upregulate surface vascular cell adhesion molecule (VCAM-1) expression. ${ }^{50}$ Such upregulation could explain an increase in the persistence or severity of inflammation in asthmatic subjects and also the observation that asthmatic children may be more susceptible to colds than non-asthmatic children. ${ }^{51}$

The effects of virus infection on epithelial cell cytokine production have been studied in bronchial epithelial cell lines. Viral infection has been shown to promote production of a number of cytokines, as demonstrated by the finding of increased amounts of cytokines in the culture supernatants and increased amounts of mRNA within the epithelial cells (table 1). Upregulation of IL-6 and IL-8 production has been reported following infection of epithelial cell lines with respiratory syncytial virus $(\mathrm{RSV})^{5253}$ and rhinovirus, ${ }^{54}$ RANTES and macrophage inflammatory protein (MIP)- $1 \alpha$ in response to RSV infection, ${ }^{55}$ granulocytemacrophage colony stimulating factor (GM$\mathrm{CSF}$ ) in response to rhinovirus, ${ }^{56}$ and IL-11 in response to RSV, parainfluenza 3, and rhinovirus. ${ }^{57}$ Rhinovirus induced epithelial cell IL-6 production has been studied in detail using the A549 epithelial cell line and its upregulation is reported to be mediated by an $\mathrm{NF}-\kappa \mathrm{B}-\mathrm{de}-$ pendent transcriptional stimulation pathway. ${ }^{58}$

IL-8 is an important neutrophil chemoattractant and evidence from induced sputum studies suggests that it may have an important role in driving exacerbations of asthma. Induced sputum taken during asthma exacerbations reveals a large group of patients in whom neutrophils are the dominant cell type with increased levels of IL-6 and IL-8 emanating from the lower airways. ${ }^{59}$ IL-8 can also act as a chemoattractant for eosinophils primed by IL $-4^{60}$ and complexed with sIgA. The role of IL-6 is less clear. Receptors for this cytokine are found on activated B cells, T cells, and monocytes and it seems to be involved in $\mathrm{T}$ cell activation, ${ }^{61}$ in inducing terminal differentiation and immunoglobulin production of 
Table 1 Summary of in vitro and in vivo studies of cytokine production categorised according to cell source and virus type

\begin{tabular}{|c|c|c|c|}
\hline Cell type & Virus & Experiment & Effect on cell function \\
\hline Epithelial & $\begin{array}{l}\text { Rhinovirus } \\
\text { RSV }\end{array}$ & In vitro & $\begin{array}{l}\text { Increased IL-6, IL-8, IL-11, } \\
\text { GM-CSF } \\
\text { Increased IL-6, IL-8, IL-11, } \\
\text { RANTES, MIP-1 } \alpha\end{array}$ \\
\hline $\begin{array}{l}\text { Peripheral blood } \\
\text { mononuclear cells }\end{array}$ & $\begin{array}{l}\text { Rhinovirus } \\
\text { Measles vaccine } \\
\text { Influenza A }\end{array}$ & $\begin{array}{l}\text { Ex vivo } \\
\text { In vitro }\end{array}$ & $\begin{array}{l}\text { Increased IL- } 6, \text { IL- } 8 \text {, TNF- } \alpha \\
\text { Increased PHA stimulated } \\
\text { IL- } 2 \text { and IFN- } \gamma \\
\text { Increased IL- } 4, \text { TNF- } \alpha \\
\text { Decreased IFN- } \gamma \text {, IL- } 1 \alpha \\
\text { Increased IFN- } \gamma \text { and IL-2 }\end{array}$ \\
\hline CD8 + cells & $\begin{array}{l}\text { Lymphocytic } \\
\text { choriomeningitis virus }\end{array}$ & $\begin{array}{l}\text { In vitro } \\
\text { In vivo }\end{array}$ & Increased IL-4, IL-5 and IL-10 \\
\hline Peripheral $\mathrm{T}$ cells & Rhinovirus & Ex vivo & Decreased $\mathrm{T}$ cell response to allergen \\
\hline Monocytes/macrophages & Influenza A & In vitro & Increased IFN- $\alpha$, IFN- $\beta$, IL- $1 \beta$, IL- 6 , TNF- $\alpha$ \\
\hline Basophils & $\begin{array}{l}\text { RSV, adenovirus } \\
\text { influenza, parainfluenza } \\
\text { Rhinovirus }\end{array}$ & $\begin{array}{l}\text { In vitro } \\
\text { Ex vivo }\end{array}$ & $\begin{array}{l}\text { Increased histamine releasability } \\
\text { Increased } \mathrm{LTC}_{4} \text { production }\end{array}$ \\
\hline
\end{tabular}

$\mathrm{RSV}=$ respiratory syncytial virus; $\mathrm{IL}=$ interleukin; $\mathrm{GM}-\mathrm{CSF}=$ granulocyte macrophage colony stimulating factor; IFN = interferon; TNF = tumour necrosis factor; PHA = phytohaemagglutinin; LTC $_{4}=$ leukotriene $\mathrm{C}_{4}$; RANTES and macrophage inflammatory protein (MIP) $-1 \alpha$ are members of the chemokine family.

B lymphocytes, and in regulating pulmonary inflammation and stimulating mucosal $\operatorname{IgA}$ immune responses. ${ }^{6263} \mathrm{IL}-11$ is a pleiotropic cytokine with effects that overlap with IL-6. RANTES is an eosinophil chemoattractant and, consistent with its upregulation by RSV, is the finding that RSV infected epithelial cells induce transendothelial migration of human blood eosinophils. ${ }^{64}$

The finding of virus induced increases in epithelial derived chemokines, such as IL-8 and RANTES, is potentially of great significance since they are directly responsible for the recruitment of inflammatory cells to the airways and there is an increasing awareness of the importance of this group of cytokines in the pathogenesis of allergic inflammation. Much future research is likely to focus on the effects of viruses on the production of other chemokines such as gro- $\alpha$, MIP- $1 \alpha$, and eotaxin.

Another epithelial derived mediator involved in asthma is nitric oxide (NO) ${ }^{6566} \mathrm{NO}$ may have an antiviral effect ${ }^{67-69}$ and may be produced as part of the immunological response to URT viruses. It is also implicated as a mediator of increased bronchial blood flow, eosinophilic infiltration, and damage to the airway epithelium, ${ }^{70}$ and may inhibit Th1 $\mathrm{T}$ cell proliferation ${ }^{71}$ by shifting the $\mathrm{T}$ cell cytokine profile towards the $\mathrm{Th} 2$ phenotype. Increased levels of exhaled NO have been detected in nonasthmatic volunteers following naturally acquired symptomatic colds with associated lower respiratory tract symptoms $\mathrm{s}^{72}$ and in asthmatic volunteers following experimental rhinovirus infection. This is in contrast to atopic and non-atopic individuals who develop naturally acquired colds without any lower respiratory tract symptoms, in which no early increase in exhaled NO can be detected. ${ }^{73}$

\section{T cells}

Clinical studies have demonstrated a $\mathrm{T}$ cell response following URT viral infection. There is a reduction in circulating $\mathrm{T}$ lymphocytes during rhinovirus infection ${ }^{74}$ with increases in
T lymphocyte counts being reported in nasal secretions ${ }^{75}$ and the lower respiratory tract. ${ }^{43}$

Studies of peripheral blood mononuclear cells have produced conflicting evidence regarding the effect of URT viruses on T cells with reports suggesting that viruses may induce both a Th1 and Th2 type cytokine response. A number of studies have suggested that viruses induce increased Th1 type cytokine production. In one such study ${ }^{76}$ peripheral blood mononuclear cells collected from volunteers five days after experimental rhinovirus infection showed the production of a Th1 type cytokine pattern with significant increases in phytohaemagglutinin (PHA) stimulated IL-2 and IFN- $\gamma$ production. Consistent with this are reports of increased levels of IFN- $\gamma$ in nasal lavage fluid during rhinovirus colds. ${ }^{477}$ In contrast, others have shown increases in Th2 type cytokine production. Peripheral blood mononuclear cells isolated from healthy volunteers following immunisation with measles vaccine and cultured for 72 hours showed no changes in the proportion of CD $4+\mathrm{T}$ cells, CD8 $+\mathrm{T}$ cells, NK cells, or B cells but there was an increased spontaneous release of IL-4 and $\mathrm{TNF}-\alpha$ with reduced levels of IFN- $\gamma$ and IL$1 \alpha .^{78}$

Although the adoption of a Th1 or Th2 cytokine profile by peripheral blood mononuclear cell cultures suggests activity of CD4+ $\mathrm{T}$ cells, there is an increasing realisation that $\mathrm{CD} 8+\mathrm{T}$ cells, when activated by virus, may make an important contribution to the cytokine pool. ${ }^{79}$ There is evidence for viruses inducing both increases in IFN- $\gamma$ and release of Th2 type cytokines from CD8 $+\mathrm{T}$ cells. Activated $\mathrm{CD} 8+\mathrm{T}$ cells are major producers of IFN $-\gamma^{80}$ and euthymic mice treated with IFN- $\gamma$ antibodies succumb to an otherwise non-lethal viral infection. ${ }^{81}$ Following infection of mice with influenza virus there is a preferential accumulation of CD8 $+\mathrm{T}$ cells in the airway and these cells show a high level of IFN- $\gamma$ mRNA expression. ${ }^{82}$ However, it has also been shown that mouse CD8 + T cells can, in the presence of IL-4, switch to a non-cytolytic CD8-CD4- 
Th2 like phenotype producing large amounts of IL-4, IL-5, and IL-10. ${ }^{83}$ Such a phenotypic switch could be exploited by viruses to reduce the antiviral activity of CD $8+\mathrm{T}$ cells and would also lead to an increase in Th2 type cytokine production. A recent report has suggested that, in the mouse, an ongoing Th2 immune response in vivo can switch a virus peptide specific CD8 $+\mathrm{T}$ cell to the production of IL-5, leading to airway eosinophilia. ${ }^{84}$ The asthmatic airway, rich in Th2 $+\mathrm{T}$ cells, would provide the ideal environment for this switch to occur, and the resulting eosinophilia would lead to a worsening of the asthma.

Thus, studies of virus induced $T$ cell cytokine production present a confusing picture. Both $\mathrm{CD} 4+$ and CD8 + T cells may be involved in cytokine production and there is evidence for increased production of both $\mathrm{Th} 1$ and $\mathrm{Th} 2$ type cytokines. Part of this confusion may be due to the fact that different viral proteins may evoke different responses. ${ }^{85}$ Also, studies have utilised both live virus and vaccines and there are important differences in the way these are processed with live virus being presented, in association with MHC class I proteins, to $\mathrm{CD} 8+\mathrm{T}$ cells $^{86}$ and dead virus/vaccines presented, in association with MHC class II proteins, to $\mathrm{CD} 4+\mathrm{T}$ cells. Both responses, however, could be used to explain virus induced exacerbations of asthma. IFN- $\gamma$, an important Th1 type cytokine, could contribute to exacerbations by increasing basophil and mast cell histamine releasability (see below), whereas increased production of IL- 4 and IL- 5 would lead to an amplification of the inflammatory response and an increase in airway eosinophilia.

We have shown interesting changes in circulating $\mathrm{T}$ cell function during symptomatic URT infection. ${ }^{87}$ Proliferation of systemic T lymphocytes to house dust mite allergen $\operatorname{Der} p \mathrm{I}$ in sensitised individuals was suppressed during the acute phase of a symptomatic URT infection compared with the convalescent phase, but there were no changes to polyclonal stimulation with the mitogen PHA. The most likely explanation is that allergen-specific $T$ cells are migrating to the airways during the cold, perhaps due to increases in airway permeability to allergen and, since they form only a small part of the total circulating $\mathrm{T}$ cell population, the effect of PHA stimulation would remain unchanged. Another explanation is that changes to the cytokine environment may affect $T$ cell proliferation. Production of the Th2 subset of cytokines, either through activation of Th2 cells or through conversion of CD $8+\mathrm{T}$ cells to the Th2 like phenotype, would suppress $\mathrm{T}$ cell proliferation.

\section{Monocytes and macrophages}

Monocytes and macrophages express high basal levels of intercellular adhesion molecule (ICAM) $-1^{88}$ and act as important constituents of the antiviral response. When infected in vitro with influenza A virus, human monocytes display dramatic changes in structure and show signs of activation lasting for 10-12 hours after infection. They mount a potent pro-in- flammatory cytokine response (table 1 ) with release of IFN- $\alpha$, IFN- $\beta$, IL- $1 \beta$, IL- 6 , and TNF- $\alpha^{89}$ which is consistent with the finding of several of these cytokines in nasal lavage fluid. Production of cytokines, with the exception of IFN- $\beta$, is further potentiated by the presence of $\mathrm{GM}-\mathrm{CSF}^{90}$ while stimulation of IFN- $\alpha$ and IFN- $\gamma$ release is blocked by addition of anti-ICAM- 1 antibodies. ${ }^{91}$ IFN- $\alpha$, IFN- $\beta$, and $\mathrm{TNF}-\alpha$ release occurs in response to live and ultraviolet inactivated virus ${ }^{92}$ whereas release of IL- $1 \beta$ and IL- 6 requires the presence of live virus. The increase in IFN- $\alpha$ is interesting in the context of virus induced exacerbations of asthma since this cytokine may have a protective effect, having recently been shown to inhibit the production of IL- 5 by human CD $4+\mathrm{T}$ cells. ${ }^{93}$ Recent work has also suggested that the protective cytokine, IL-10, may be produced by human blood derived monocytes infected in vitro with $\mathrm{RSV}^{94}$ and, indeed, IL-10 is expressed in lymph node cells in mice following infection with influenza virus. ${ }^{95} \mathrm{IL}-10$ is an anti-inflammatory cytokine which inhibits the production of cytokines associated with allergic inflammation such as IL4 and IL-5. ${ }^{96}$ Presumably the protective effect of these cytokines is outweighed by the proinflammatory effects of viral infection described above.

\section{Basophil function}

Although the role of the basophil in asthma remains controversial, it is known that URT infection leads to major changes in basophil function. In vitro incubation of basophils with virus does not in itself cause release of mediators, but a number of viruses (RSV, adenovirus, influenza, and parainfluenza) have been shown to enhance the histamine release that occurs when basophils are stimulated by cross linking of bound $\operatorname{IgE}$ with an anti- $\operatorname{IgE}$ antibody. ${ }^{9798}$ These effects have also been shown ex vivo with basophils from asthmatic volunteers showing consistently increased levels of anti-IgE stimulated histamine release during the acute phase compared with the convalescent phase of symptomatic colds. ${ }^{99}$ In a recent study we have confirmed these findings and have also shown that URT viral infection augments the increases in histamine release and leukotriene $\mathrm{C}_{4}$ production that occur in response to cross linking of VLA 4. These effects are specific since there is no increase to the non-specific stimuli of calcium ionophore of F-met peptide. ${ }^{100}$

The mechanism of basophil activation is unclear since few basophils will come in contact with viruses in the URT, and systemic spread of URT viruses has not been shown. Activation may involve another mediator released locally by the URT with some studies suggesting that the interferons resulting from the URT may act to enhance histamine release. ${ }^{101}$

If these observations are relevant one would expect increased levels of histamine in the airways or circulation during symptomatic colds. Studies have suggested increased levels of histamine during URT infection both in nasal 
secretions and in plasma, ${ }^{102}$ but these have involved children sufficiently ill to be admitted to hospital or subjects developing a late phase reaction following allergen challenge. ${ }^{15}$ One study has also shown an increase in histamine levels in nasal secretions of atopic individuals following experimental rhinovirus infection ${ }^{103}$ but, in contrast, a study of 16 volunteers with no history of atopy failed to show any changes in the histamine levels in nasal secretions during naturally acquired colds. ${ }^{104}$ We have also failed to show significant increases in nasal secretion histamine levels both in non-atopic and atopic individuals, ${ }^{47}$ although several subjects did appear to have high levels in their lavage fluid. One explanation may be the timing of the acute sample which was taken slightly later (2-4 days) after inoculation in the positive study.

The effect of viruses on the mast cell has not been the subject of much study because of the difficulty of obtaining adequate numbers of mast cells. Animal studies have suggested that similar effects may occur with increased release of histamine from calf mast cells being demonstrated following infection with parainfluenza virus ${ }^{105}$ and increased numbers of mast cells have been found in the airway of Brown Norway rats infected with parainfluenza 1 virus. ${ }^{106}$

\section{Kinins}

Kinins are peptidic hormones formed in tissues and fluids that may be involved in the pathogenesis of asthma through both a bronchoconstrictive and proinflammatory action. Bradykinin, for example, as well as causing bronchoconstriction, ${ }^{107}$ increases microvascular leakage in guinea pig airways ${ }^{108}$ and increases mucus secretion. ${ }^{109}$

Levels of kinins in nasal secretions have been shown to rise following both experimental rhinovirus infection and naturally acquired colds $^{104}$ and levels of TAME-esterase activity, which reflects the presence of kinin generating enzymes, have been shown to increase in parallel. ${ }^{110}$ Some studies ${ }^{110}$ have shown a positive correlation between levels of kinins and cold symptoms but others have failed to confirm this. ${ }^{11}$

\section{Systemic IgE production}

Viral infection has been likened to the onset of atopy ${ }^{112}$ and increases in systemic IgE levels have been found following infection with the Epstein-Barr virus (EBV), ${ }^{113}$ cytomegalovirus (CMV), and the measles virus, ${ }^{114}$ and following vaccination with whole virion influenza vaccine. ${ }^{115}$ In one study ${ }^{116}$ increases in circulating blood IgE were demonstrated in 103 patients with serologically confirmed upper and lower respiratory tract infections. Increases in total serum IgE levels have also been noted following experimental rhinovirus infection. ${ }^{117}$

Increases in $\operatorname{IgE}$ levels could be viral or allergen-specific or could simply represent a generalised upregulation of $\operatorname{IgE}$ production. In a small study of 12 children with asthma attacks precipitated by influenza the levels of house dust mite-specific IgE increased during the acute phase although total serum IgE levels remained unchanged. ${ }^{118}$ However, other workers have shown a rise in total serum IgE levels following rhinovirus infection with no rise in pre-existing specific IgE levels. ${ }^{117}$ Others have suggested that the $\operatorname{IgE}$ response may be virally directed. RSV infection has been shown to induce the production of virus-specific IgE, the magnitude of the response correlating with degree of wheezing and children with an atopic predisposition developing an $\operatorname{IgE}$ response more readily. ${ }^{119}$ Specific IgE antibodies to parainfluenza virus ${ }^{120}$ and Mycoplasma pneumoniae $^{121}$ have also been demonstrated.

Although epidemiological studies have shown an association between IgE levels and severity of asthma, there is no evidence that increases in IgE levels are involved in the aetiology of the acute attack. It is more likely that increases in IgE levels are secondary to other changes in the inflammatory pathway. One possibility is that Th1 like $T$ cells are recruited to the site of infection, leading to a predominance of Th2 like cells in the circulation and increases in circulating IgE levels. Another possibility would be the switch of CD8 + cells to the Th2 phenotype resulting in increases in IgE production. A knowledge of the effect of viral infection on local IgE production would be helpful in further developing an hypothesis.

\section{Virus in the lower respiratory tract}

The finding of URT viruses in the lower respiratory tract would add potential new mechanisms for the explanation of virus induced exacerbations of asthma. A number of URT viruses - for example, influenza and RSV - can cause pneumonia, providing evidence for their invasion of the lower respiratory tract. Persistent adenovirus has recently been found in the lower respiratory tract of children with a history of wheeze following acute adenovirus bronchiolitis. ${ }^{122}$ Using immunofluorescence adenovirus capsid antigen could be detected in samples of bronchoalveolar lavage fluid in 31 of the 34 children and in all six children in whom culture was attempted its viability was confirmed. In contrast, no virus was found in a group of 20 control children admitted to the same hospital department and studied during the same period.

Evidence that rhinovirus invades the lower respiratory tract is more difficult to obtain. Rhinoviruses grow best at $33^{\circ} \mathrm{C}$, the ambient temperature of the URT, thus the higher temperature of the lower airways would be expected to discourage their growth. Temperatures in the tracheobronchial tree lower than $37^{\circ} \mathrm{C}$ have, however, been described ${ }^{123}$ and may occur secondary to the mouth breathing that accompanies nasal blockage. Nevertheless, rhinovirus has been recovered from necroscopic studies of lung tissue from patients with myelomatosis ${ }^{124}$ and from the lungs of an 11 month old infant dying from asthma. ${ }^{125}$ In addition, viral cultures from sputum are more often positive for rhinovirus than from throat and nasal swabs, suggesting that viral replication may 


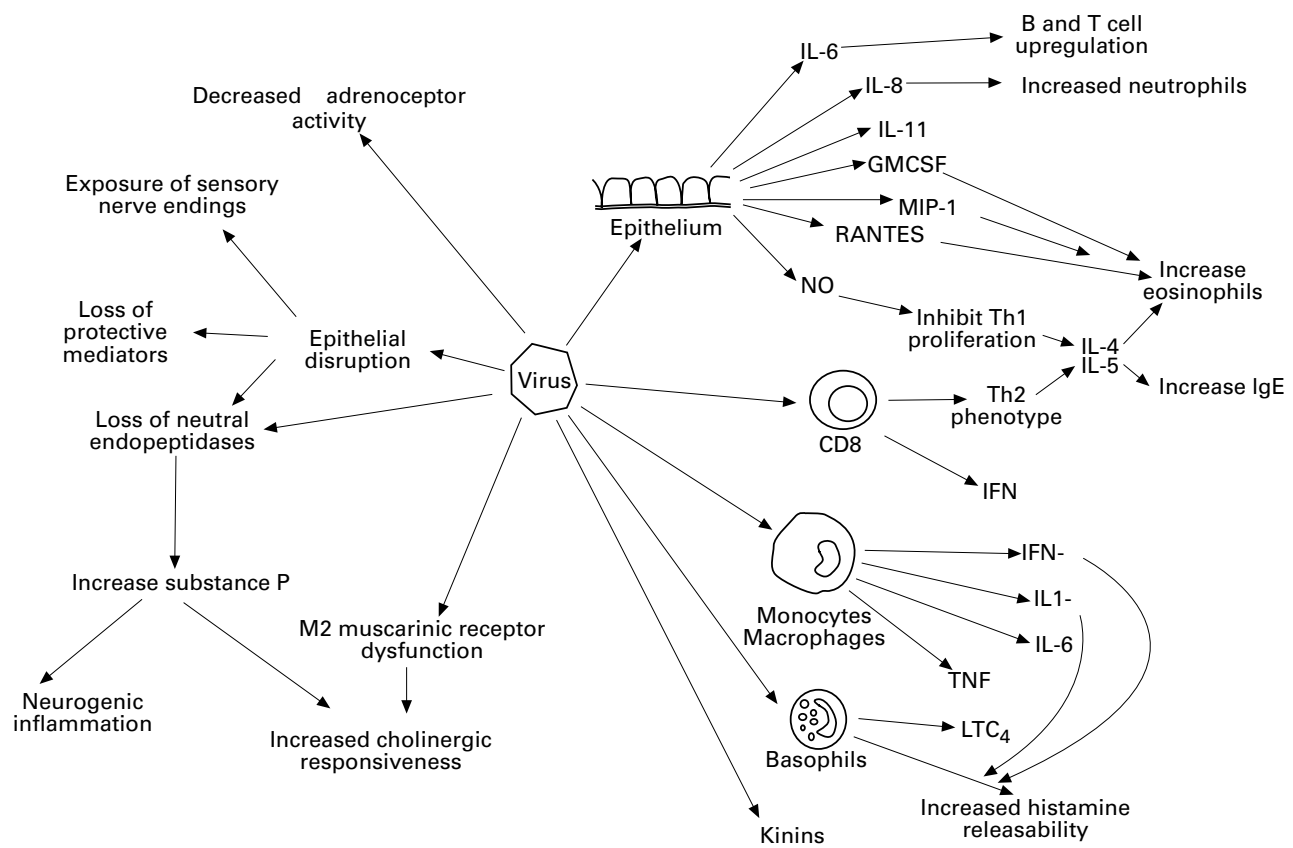

Figure 1 Summary of the effects of viruses of the upper respiratory tract (URT) that may lead to exacerbations of asthma. $I L=$ interleukin, GM-CSF = granulocyte macrophage colony stimulating factor, RANTES and MIP-1 $\alpha$ are members of the chemokine family, IFN = interferon, $T N F=$ tumour necrosis factor, $L T C_{4}=$ leukotriene $C_{4}$. URT viruses (centre) have been shown to lead to decreases in $\beta$ adrenoceptor activity and to cause epithelial disruption leading to exposure of sensory nerve endings, loss of protective mediators, and loss of neutral endopeptidases. They may directly reduce neutral endopeptidase activity and this reduction can lead to increases in levels of substance $P$ and both potentiation of cholinergic responsiveness and the development of neurogenic inflammation. URT viruses have also been shown to act directly on the muscarinic receptor leading to increases in cholinergic responsiveness, and to interact with airway epithelium leading to increases in IL-6, IL-8, IL-11, GM-CSF, and the chemokines MIP-1 $\alpha$ and RANTES leading to $B$ and $T$ cell upregulation and increased numbers of eosinophils and neutrophils. This interaction may also lead to increases in nitric oxide (NO) which may inhibit Th1 proliferation and lead, through increases in levels of IL-4 and IL-5, to an airway eosinophilia and increases in IgE production. URT viruses may act on CD8 + T lymphocytes to cause a shift to a Th2 type pattern of cytokine production. They have also been shown to act on monocytes and macrophages leading to increased production of IFN- $\beta, I L-1 \beta, I L-6$, and TNF- $\alpha$, and to act on basophils leading to increases in basophil histamine releasability (perhaps through increased production of IFN- $\beta$ and IL-1 $\beta$ ) and LTC production. Finally, URT viral infection may lead to increases in the levels of kinins. All these factors may contribute to the development of exacerbations of asthma following URT infection.

occur in the lower airways, ${ }^{126}$ and bronchoscopic studies following experimentally induced rhinovirus infection have enabled viral isolation from bronchoalveolar lavage fluid. ${ }^{127} 128$

Necroscopic and bronchoscopic studies suffer from the criticism that the presence of viruses can result from contamination. Conclusive proof relies on the demonstration of viral genome within cells of the lower respiratory tract by in situ techniques. These have been developed and used with success to localise rhinovirus in the epithelial cells of nasal mucosa ${ }^{129}$ and must now be applied to the lower airways.

\section{Conclusion}

URT viruses are major precipitants of exacerbations of asthma and cause significant increases in BHR in both normal and asthmatic subjects. It is important to understand the mechanisms of virus induced exacerbations of asthma but the paucity of information so far available makes it difficult to propose an all embracing hypothesis.

In this review we have described a number of mechanisms by which URT viral infection may contribute to increases in BHR and the development of asthma exacerbations. With regard to the immunological changes, the cells and cytokines involved (table 1, fig 1) may differ from those thought to be important in generating the underlying inflammatory response with, for example, CD8 $+\mathrm{T}$ cells, basophils, and the neutrophil chemoattractant IL-8 assuming a greater importance. Much work needs to be done to delineate further the mechanisms of virus induced exacerbations of asthma, but the understanding of these mechanisms should open up new and potentially useful pathways for therapeutic intervention.

We would like to thank Dr S L Johnston for his help with the preparation of this manuscript.

1 Djukanovic R, Roche WR, Wilson JW, Beasley CRW, Twentyman OP, Howarth PH, et al. Mucosal inflammation in asthma. Am Rev Respir Dis 1990;142: 434-57.

2 Storr J, Lenney W. School holidays and admissions with asthma. Arch Dis Child 1989;64:103-7.

3 Minor TE, Dick EC, De Meo AN, Ouellette JJ, Cohen $M$, Reed CE. Viruses as precipitants of asthmatic attacks in children. $7 A M A$ 1974;227:292-8.

4 Johnston S, Pattemore P, Sanderson G, Smith S, Lampe F, Josephs L, et al. Community study of the role of viral infections in exacerbations of asthma in 9-11 year old children. BMF 1995;310:1225-9.

5 Kent J, Ireland D, Nicholson K. Respiratory viruses and exacerbations of asthma in adults. BMF 1993;307:982-6.

6 Johnston SL, Bardin PG, Pattemore PK. Viruses as precipitants of asthma symptoms. III. Rhinoviruses: molecular biology and prospects for future intervention. Clin Exp Allergy 1993;23:237-46. 
7 Empey DW, Laitnen LA, Jacobs L, Gold WM, Nadel JA. Mechanisms of bronchial hyperreactivity in normal subjects after upper respiratory tract infection. Am Rev Respir Dis 1976;113:131-9.

8 Hudgel DW, Langston L, Selner J, McIntosh K. Viral and bacterial infections in adults with chronic asthma. Am Rev Respir Dis 1979;120:393.

9 Laitinen LA, Elkin RB, Empey DW, Jacobs L, Mills J, Nadel JA. Bronchial hyperresponsiveness in normal subjects during attenuated influenza virus infection. Am Rev Respir Dis 1991;143:358-61.

10 Laitinen L, Kava T. Bronchial reactivity following uncomplicated influenza A infection in healthy subjects and complicated influenza A infection in healthy subjects
asthmatic patients. Eur $\mathcal{F}$ Respir Dis 1980;106:51-8.

11 Little JW, Hall WJ, Douglas Jr G, Mudholkur GJ, Speers DM, Patel K. Airway hyperreactivity and peripheral airway dysfunction in Influenza A infection. Am Rev Respir Dis 1978;118:295-303.

12 Anand SC, Itkin IH, Kind LS. Effect of influenza vaccine on metacholine sensitivity in patients with asthma of known and unknown origin. F Allergy 1968;42:187.

13 Ouellete JJ, Reed CE. Increased response of asthmatic subjects to metacholine after influenza vaccine. F Allergy 1965;36:558.

14 Cheung D, Dick E, Timmers M, de Klerk E, Spaan W, Sterk P. Rhinovirus inhalation causes long lasting excessive airways narrowing in response to methacholine in asymptomatic subjects in vivo. Am 7 Respir Crit Care Med 1995;152:1490-6.

15 Calhoun WJ, Swanson CA, Dick EC, Schwartz LB, Lemanske RFJ, Busse WG. Experimental rhinovirus 16 infection potentiates histamine release after antigen bronchoprovocation in allergic subjects. Am Rev Respir Dis 1991;144:1267-73.

16 Henderson FW, Hu S-C, Collier AM. Pathogenesis of respiratory syncitial virus infection in ferret and fetal human tracheas in organ culture. Am Rev Respir Dis 1978; 118:29-37.

17 Ramphael R, Fischlschweiger W, Shands JW, Small Parker Jr A. Murine influenzal tracheitis: A model for the study of influenza and tracheal epithelial repair. Am Rev Respir of influenza and trache

18 Richardson JB, DeNotaris A, Fergusson CC, Boucher RC. Effects of viral laryngotracheitis on the epithelial barrier of chicken airways. Lab Invest 1981;44:144-50.

19 Riedel F, Krause A, Slenczka W, Rieger C. Parainfluenza3 -virus infection enhances allergic sensitization in the guinea-pig. Clin Exp Allergy 1996;26:603-9.

20 Castleman W. Alteration in pulmonary ultrastructure and morphometric parameters induced by parainfluenza (Sendai ) virus in rats during postnatal growth. Am F Pathol 1984;114:322-35.

21 Castleman W. Respiratory tract lesions in weanling outbred rats infected with Sendai virus. Am $\mathcal{F}$ Vet Res 1983;44: 1025-32.

22 Walsh JJ, Dietlein LF, Low FN, Bunch GE, Mogabgab WD. Bronchotracheal response in human influenza. Arch Intern Med 1961;108:376.

23 Camner P, Jarstrand C, Philipson K. Tracheobronchial clearance in patients with influenza. Am Rev Respir Dis 1973;108:131-5

24 Sasaki Y, Togo Y, Wagner H, Hornicak R, Swartz A, Proctor D. Mucociliary function during experimentally induced rhinovirus

25 Szentivanyi A. The beta-adrenergic theory of atopic abnormality in asthma. F Allergy 1968;42:203-23.

normality in asthma. F Allergy 1968;42:203-23.
26 Buckner CK, Clayton DE, Ain-Shoka AA, Busse Ww, Dick EC, Shult P. Parainfluenza 3 infection blocks the ability of a beta-adrenergic receptor agonist to inhibit antigen-induced contraction of guinae pig isolated airway smooth muscle. $\mathcal{F}$ Clin Invest 1981;67:376-84.

27 Scarpace PJ, Bender BS. Viral pneumonia attenuates adenylate cyclase but not beta adrenergic receptors in murine lung. Am Rev Respir Dis 1989;140:1602-6.

28 Busse WW. Decreased granulocyte response to isoproterenol in asthma during upper respiratory tract infection. Am Rev Respir Dis 1977;115:783-91.

29 Buckner C, Songsiridej V, Dick E, Busse W. In vivo and in vitro studies on the use of the guinea pig as a model for virus-provoked airway hyperreactivity. Am Rev Respir Dis 1985;132:305-10.

30 Fryer A, Jacoby D. Parainfluenza virus infection damages inhibitory M2 muscarinic receptors on pulmonary parasympathetic nerves in the guinea pig. Br f Pharmacol 1991;102:267-71.

31 Fryer A, El-Fakahany E, Jacoby D. Parainfluenza virus type 1 reduces the affinity of agonists for muscarinic receptors in guinea-pig lung and heart. Eur 7 Pharmacol 1990;181:51-8.

32 Fryer A, Yarkony K, Jacoby D. The effect of leukocyte depletion on pulmonary M2 muscarinic receptor function in parainfluenza virus infected guinea pigs. Brf Pharmacol in parainfluenza virus

33 Sorkness R, Clough JJ, Castleman WL, Lemanske RJ. Virus-induced airway obstruction and parasympathetic hyperresponsiveness in adult rats. Am f Respir Crit Care Med 1994;150:28-34.

34 Barnes P. Modulation of neurotransmission in the airways. Physiol Rev 1992;72:699-729.

35 Tanaka D, Grunstein M. Mechanisms of substance Pinduced contraction of rabbit airway smooth muscle. $\mathcal{f}$ Appl Physiol 1984;57:1551-7.
36 Barnes P, Baraniuk J, Belvisi M. Neuropeptides in the respiratory tract. Part 1. Am Rev Respir Dis 1991;144 1187-98.

37 Barnes P, Baraniuk J, Belvisi M. Neuropeptides in the respiratory tract. Part II. Am Rev Respir Dis 1991;144: 1391-9.

38 Dusser D, Jacoby D, Djokic T, Rubinstein I, Borson D, Nadel J. Virus induces airway hyperresponsiveness to tachykinins: role of neutral endopeptidase. F Appl Physiol 1989;67:1504-11.

39 Yamawaki I, Geppetti P, Bertrand C, Chan B, Massion P, Piediminte G, et al. Viral infection potentiates the increase in airway blood flow produced by substance P. $\mathcal{F} A p p l$ in airway blood flow produr

40 Jacoby D, Tamaoki J, Borson D, Nadel J. Influenza infection causes airway hyperresponsiveness by decreasing enkephalinase. F Appl Physiol 1988;64:2653-8.

41 Borson D, Brokaw J, Sekizawa K, McDonald D, Nadel J. Neutral endopeptidase and neurogenic inflammation in rats with respiratory infections. F Appl Physiol 1989;66: 2653-8.

42 Calhoun W, Dick E, Schwartz L, Busse W. A common cold virus, rhinovirus 16 , potentiates airway inflammation after segmental antigen bronchoprovocation in allergic subjects. $\mathcal{F}$ Clin Invest 1994;94:2200-8.

43 Fraenkel D, Bardin P, Sanderson G, Lampe F, Johnston S, Holgate $S$. Lower airways inflammation during rhinovirus colds in normal and asthmatic subjects. Am Rev Respir Dis $1995 ; \mathbf{1 5 1}: 879-86$.

44 Trigg C, Nicholson $\mathrm{K}$, Wang J, Ireland $\mathrm{D}$, Jordan $\mathrm{S}$, Duddle J, et al. Bronchial inflammation and the common cold: a comparison of atopic and non-atopic individuals. Clin Exp Allergy 1996;26:665-78.

45 Teran L, Johnston S, Shute J, Church M, Holgate S. Increased levels of Interleukin-8 in the nasal aspirates of children with viral associated asthma. $\mathcal{F}$ Allergy Clin Immunol 1994;93:272.

46 Cheung D, Hiemstra PS, Dick EC, de Klerk EPA, Sterk PJ. Effects of experimental rhinovirus infection on IL-8 in nasal washings in asthmatic subjects in vivo. Eur Respir f $1994 ; 7: 481 \mathrm{~s}$

47 Lau L, Corne J, Scott S, Davies R, Friend E, Howarth P. Nasal cytokines in the common cold. Am 7 Respir Crit Care Med 1996;153:A697.

48 Staunton D, Merluzzi V, Rothlein R, Barton R, Marlin S, Springer T. A cell adhesion molecule, ICAM-1, is the major surface receptor for rhinoviruses. Cell 1989;56: major surfa-53.

49 Greve JM, Davis L, Meyer AM, Forte CP, Yost S, Marlow $\mathrm{CW}$, et al. The major human rhinovirus receptor is ICAM 1. Cell 1989;56:839-47.

50 Papi A, Wilson S, Johnston S. Rhinoviruses increase production of cell adhesion molecules (CAM) and NF- $\mathrm{KB}$ Am $\mathcal{F}$ Respir Crit Care Med 1996;153:A866.

51 Johnston S, Pattemore P, Lampe F, Holgate S. The role of asthma and atopy in the suceptibility to respiratory viral infection in children. Am f Respir Crit Care Med 1994;149:A50.

52 Noah TL, Becker S. Respiratory syncytial virus-induced cytokine production by a human bronchial epithelial cell line. Am 7 Physiol 1993;265:L472-8.

53 Becker S, Koren H, Henke D. Interleukin-8 expression in normal nasal epithelium and its modulation by infection with respiratory syncytial virus and cytokines tumor necwith respiratory syncytial virus and cytokines tumor necrosis factor, interleukin-1, and Biol 1993;8:20-7.

54 Elias J, Zheng T, Einarsson O, Landry M, Trow T, Rebert $\mathrm{N}$, et al. Epithelial interleukin-11: regulation by cytokines, respiratory syncytial virus and retinoic acid. $\mathcal{f}$ Biol Chem 1994;269:22261-8

55 Siddiqi A, Peeples M, Brees B, Moy J. Respiratory syncytia virus-induced release of RANTES and MIP-1 by bronchial epithelial and peripheral mononuclear cells. $\mathcal{F}$ Allergy Clin Immunol 1996;37:305.

56 Subauste M, Jacoby D, Richards S, Proud D. Infection of a human respiratory epithelial cell line with rhinovirus. $\mathcal{F}$ Clin Invest 1995;96:549-57.

57 Einarsson O, Geba G, Zhu Z, Landry M, Elias J. Interleukin-11: stimulation in vivo and in vitro by respiratory viruses and induction of airway hyperresponsiveness. $\mathcal{F}$ Clin Invest 1996;97:915-24.

58 Zhu Z, Tang W, Ray A, Wu Y, Einarsson O, Landry M, et al. Rhinovirus stimulation of interleukin-6 in vivo and et al. Rhinovirus stimulation of interleu
in vitro. $\mathcal{F}$ Clin Invest 1996;97:421-30.

59 Fahy J, Kim K, Liu J, Boushey H. Prominent neutrophilic inflammation in sputum from subjects with asthma exacerbation. F Allergy Clin Immunol 1995;95:843-52.

60 Villar M, Douglass J, Shute J, Church M, Holgate S Interleukin-8 is a chemoattractant for eosinophils primed with interleukin-4. Am Rev Respir Dis 1993;147:A242.

61 Akira S, Taga T, Kishimoto T. Interleukin-6 in biology and medicine. Adv Immunol 1993;54:1-78.

62 DiCosmo B, Geba G, Picarella D, Elias J, Rankin A, Stripp B, et al. Airway epithelial cell expression of interleukin-6 in transgenic mice. Uncoupling of airway inflammation in transgenic mice. Uncoupling of airway inflammation and 35 .

63 Ramsay A, Husband A, Ramshaw I, Bao S, Matthaei G Koehler G, et al. The role of interleukin-6 in mucosa IgA antibody responses in vivo. Science 1994;264:561-3.

64 Olszewska B, Mei F, Ogra P, Garofalo R. Respirator syncytial virus (RSV)-infected airway epithelial cells in-
duce transendothelial migration of human blood eosinophils. f Allergy Clin Immunol 1996;97:283. 
65 Hamid Q, Springall D, Riveros-Moreno V, Chanez P, Howarth $\mathrm{P}$, Redington $\mathrm{A}$, et al. Induction of nitric oxide synthase in asthma. Lancet 1993;342:1510-3.

66 Kharitonov S, Yates D, Springall D, Buttery L, Polak J, Robbins R, et al. Exhaled nitric oxide is increased in asthma. Chest 1995;107:156-7s.

67 Croen K. Evidence for an antiviral effect of nitric oxide. f Clin Invest 1993;91:2446-52.

68 Karupiah G, Xie Q, Buller M, Nathan C, Duarte C, MacMicking J. Inhibition of viral replication by interferon gamma ind

69 Lowenstein C, Hill S, Laford-Walker A, Wu J, Allen G, Landevere $M$, et al. Nitric oxide inhibits viral replication Landevere $M$, et al. Nitric oxide inhibits viral replication

70 Gaston B, Drazen J, Loscalzo J, Stamler J. The biology of nitrogen oxides in the airways. Am f Respir Crit Care Med 1994;149:538-51

71 Taylor-Robinson A, Liew F, Severn A, Xu D, McSorley $\mathrm{S}$, Garside $\mathrm{P}$, et al. Regulation of Th2 immune response by NO differentially produced by T helper type 1 and T helper type 2 cells. Eur f Immunol 1994;24:980-4.

72 Kharitonov S, Yates D, Barnes P. Increased nitric oxide in exhaled air of normal human subjects with upper respiratory tract infections. Eur Respir f 1995;8:295-7.

33 Corne J, Lau L, Scott S, Davies R, Friend E, Howarth P. Nitric oxide levels during upper respiratory trac

74 Levandowski R, Ou D, Jackson G. Acute-phase decrease Levandowski R, Ou D, Jackson G. Acute-phase decrease
of T lymphocyte subsets in rhinovirus infection. F. Infect Dis 1986;153:743-8.

75 Levandowski R, Weaver C, Jackson G. Nasal-secretion leukocyte populations determined by flow cytometry during acute rhinovirus infection. F Med Virol 1988;25:42332

76 Hsia J, Goldstein A, Simon G, Sztein M, Hayden F. Peripheral blood mononuclear cell interleukin-2 and interferon- $\gamma$ production, cytotoxicity, and antigen-stimulated blastogenesis during experimental rhinovirus infection. F Infect Dis 1990;162:591-7.

77 Noah T, Henderson F, Wortman I, Devlin R, Handy J, Koren $\mathrm{H}$, et al. Nasal cytokine production in viral upper respiratory

78 Ward BJ, Griffin DE. Changes in cytokine production after measles virus vaccination: predominant production of IL4 suggests induction of a Th2 response. Clin Immunol Immunopathol 1993;67:171-7.

79 Ramsay AJ, Ruby J, Ramshaw IA. A case for cytokines as effector molecules in the resolution of virus infection. Immunol Today 1993;14:155-7.

80 Morris A, Lin Y, Askonas B. Immune interferon release when a cloned cytotoxic T-cell line meets its correct influenza infected target cell. Nature 1982;295:150-2.

81 Ruby J, Ramshaw I. The anti-viral activity of immune $\mathrm{CD} 8+\mathrm{T}$ cells is dependent on IFN $\gamma$. Lymphokine Cytokine Res 1991;10:353-8.

82 Baumgarth N, Brown L, Jackson D, Kelso A. Novel features of the respiratory tract T-cell response to influenza virus infection: lung T cells increase expression of gamma interferon $\mathrm{mRNA}$ in vivo and maintain high levels of mRNA expression for interleukin-5 and interleukin-10. f Virol 1994;68:7575-81.

83 Erard F, Wild M-T, Garcia-Sanz J, Le Gros G. Switch of CD8 T cells to noncytolytic CD8-CD4- cells that make CD8 T cells to noncytolytic CD8-CD4- cells that make

84 Coyle A, Erard F, Bertrand C, Walti S, Pircher H, LeGros G. Virus specific CD8 cells can switch to IL-5 production and induce airway eosinophilia. F Exp Med 1995;181: 1229-33.

85 Alwan W, Kozlowska W, Openshaw P. Distinct types of lung disease caused by functional subsets of antiviral T cells. $\mathcal{F}$ Exp Med 1994;179:81-9.

86 Yewdell J, Bennink J, Hosaka Y. Cells process exogenous proteins for recognition by cytotoxic $\mathrm{T}$ lymphocytes. Science 1988;239:637-40.

87 Promwong C, Stanciu L, Corne J, Holgate S, Djukanovic R. T lymphocyte responsiveness to house dust mite in atopic asthmatic patients with respiratory tract viral inatopic asthmatic patients with respiratory tract viral
fections. Am $\mathcal{F}$ Respir Crit Care Med 1995;151:A215.

88 Kamp S, Kreff B, Braun J, Dalhaff K. A rapid semi automatic enzyme linked immunoassay identifying in-
tercellular adhesion molecule-1 (ICAM-1) on the alveolar tercellular adhesion molecule-1 (ICAM-1) on the alveolar macrop

89 Peschke T, Bender A, Nain M, Gemsa D. Role of macrophage cytokines in influenza A virus infections. Immunobiology 1993;189:340-55.

90 Bender A, Amann U, Jager R, Nain M, Gemsa D. Effect of granulocyte/macrophage colony-stimulating factor on human monocytes infected with influenza A virus. Enhancement of virus replication, cytokine release, and cytotoxicity. F Immunol 1993;151:5416-24.

91 Vrtis R, Dick E, Gern J, Busse W. The effect of rhinovirus (RV) 16 on mononuclear cell generation of $\alpha$ and $\gamma$ interferon (IFN). 7 Allergy Clin Immunol 1996;97:283.

92 Gern J, Dick E, Lee W, Murray S, Meyer K, Handzel Z, et al. Rhinovirus enters but does not replicate inside monocytes and airway macrophages. F Immunol 1996; 156:621-7.

93 Schandene L, Franco G, Prete F, Cogan E, Stordeur P, Crusiaux $\mathrm{A}$, et al. Recombinant interferon-alpha selectively inhibits the production of interleukin- 5 by human CD4 + T cells. F Clin Invest 1996;97:309-15.
94 Panuska J, Merolla R, Rebert N, Hoffmann S, Tsiuitse $\mathrm{P}$, Cirino $\mathrm{N}$, et al. Respiratory syncytial virus induce interleukin- 10 by human alveolar macrophages. Suppression of early cytokine production and implication for incomplete immunity. F Clin Invest 1995;96:2445-53.

95 Saranar S, Doherty P. Concurrent production of interleukin-2, interleukin-10 and gamma interferon in the regional lymph nodes of mice with influenza pneumonia. 7 Virol 1994;68:3112-8.

96 Del Prete G, DeCarli M, Almerigogna F, Giudizi $M$, Biagiotti R, Romagnani S. Human IL-10 is produced by biagiotti R, Romagnani S. Human IL-10 is produced by
both type 1 helper (Th1) and type 2 helper (Th2) T cell both type 1 helper (Th1) and type 2 helper (Th2) T cell clones and inhibits their antigen-specific proliferation
cytokine production. F Immunol 1993;150:353-60.

97 Clementson P, Kristenson KS, Norn S. Virus, bacteria and lipopolysacharide increase basophil cell response to histamine releasing stimulators and calcium. Allergy 1991 46:135-41.

98 Sanchez-Legrand F, Smith TF. Interaction of paromyxovirus with human basophils and their effect on histamine release. F Allergy Clin Immunol 1989;84:538-46.

99 Thomas L, Bardin P, Fraenkel D, Holgate S, Warner J. Infection with human rhinovirus (HRV) increases priming by $\alpha$ or $\gamma$ interferon (IFN) in human basophils. $\mathcal{F}$ Allergy Clin Immunol 1993; 93:197.

100 Thomas L, Corne J, Holgate S, Warner J. Integrin clustering causes increased histamine release (HR) form basophils of patients with symptomatic colds. FASEB basophils of patien

101 Ida S, Hooks JJ, Siraganian RP, Notkins AL. Enhancement of IgE mediated histamine release from human basophil by viruses: role of interferon. F Exp Med 1977;145:892 906

102 Smith TF, Remingo LK. Histamine in nasal secretions may be elevated during viral respiratory tract infections. Int Arch Allergy Appl Immunol 1982;67:380.

103 Igarashi Y, Skoner D, Doyle W, White M, Fireman P, Kaliner M. Analysis of nasal secretions during experimental rhinovirus upper respiratory tract infection. $\mathcal{F}$ Allergy Clin Immunol 1993;92:722-31.

104 Proud D, Naclerio R, Gwaltney J, Hendley J. Kinins are generated in nasal secretions during natural rhinovirus generated in nasal secretions during
colds. F Infect Dis 1990;161:120-3.

105 Ogunbiyi P, Black W, Eyre P. Parainfluenza 3 virus-induced enhancement of histamine release from calf lung mas cells; effect of levamisole. $\mathcal{F}$ Vet Pharmacol Ther 1988;11 338-44.

106 Sorden S, Castleman W. Virus-induced increases in airway mast cells in brown Norway rats are associated with enhanced pulmonary viral replication and persisting
lymphocytic infiltration. Exp Lung Res 1995;21:197-213.

107 Herxheimer H, Stresemann E. The effect of bradykinin aerosol in guinea-pigs and in man. $\mathcal{F}$ Physiol 1961;158: 38-9P.

108 Ichinose M, Barnes P. Bradykinin-induced airway microvascular leakage and bronchoconstriction are mediated via a bradykinin $\mathrm{B}_{2}$ receptor. Am Rev Respir Dis 1990; 142:1104-7.

109 Baraniuk J, Lundgren J, Mizogwhi H, Peden D, Gawin A, Merida A, et al. Bradykinin and respiratory mucous membranes. Analysis of bradykinin binding sites distribution and secretory responses in vitro and in vivo. $A m$ Rev Respir Dis 1990;141:706-14.

110 Naclerio R, Proud D, Lichtenstein L, Kagey-Sobotka A, Hendley J, Sorrentino J, et al. Kinins are generated during experimental rhinovirus colds. F Infect Dis 1987;157:13342 .

111 Skoner D, Shibayama Y, Doyle W, Seroky J, Fireman P, Cohen S, et al. Effect of experimental rhinovirus (RV-39) infection on nasal bradykinin (BK) levels. f Allergy Clin infection on nasal brad

112 Frick OL, German DF, Mills J. Development of allergy in children: association with virus infection. $\mathcal{F}$ Allergy Clin Immunol 1979;64:228-41.

113 Bahna SL, Horwitz CA, Fiala M, Heiner DL. IgE response in heterophil-positive infectious mononucleosis. F Allergy Clin Immunol 1978;62:167-73.

114 Griffin DE, Cooper SJ, Hirsch RC, Johnson RJ, Lindo de Soriano I, Roedenbeck S, et al. Changes in plasma $\mathrm{IgE}$ levels during complicated and uncomplicated measles virus infections. F Allergy Clin Immunol 1985;76:206-13.

115 Mirchaels AA, Stevens MB, Adkinson Jr NF. Detection of influenza vaccine specific IgE. F Allergy Clin Immunol influenza vaccin

116 Perelmutter L, Potvin L, Phipps P. Immunoglobulin E response during viral infections. F Allergy Clin Immuno 1979;64:127-30

117 Skoner D, Doyle W, Tanner E, Kiss J, Fireman P. Effect of rhinovirus 39 (RV-39) infection on immune and inflammatory parameters in allergic and non-allergic subjects. Clin Exp Allergy 1995;25:561-7.

118 Lin C, Kuo W, Lin W, Lin C. Immunomodulation of influenza virus infection in the precipitating asthma attack. Chest 1988;93:1234-8.

119 Welliver RC, Wong DT, Sun M, Middleton Jr E, Vaughan RS, Ogra PL. The development of respiratory syncitial virus-specific IgE and the release of histamine in nasopharyngeal secretions after infection. N Engl f Med 1981 305:841-6.

120 Welliver R, Wong D, Middleton E, Sun M, McCarthy $N$, Ogra P. Role of parainfluenza virus-specific IgE in pathogenesis of croup and wheezing subsequent to infection. F Pediatr 1982;101:889-96. 
121 Tipirneni P, Moore B, Hyde J, Schauf V. IgE antibodies to Mycoplasma pneumoniae in asthma and other atopic diseases. Ann Allergy 1980;45:1-7.

122 Macek V, Sorli J, Kopriva S, Marin J. Persistent adenoviral infection and chronic airway obstruction in children. $\mathrm{Am}$ f Respir Crit Care Med 1994;150:7-10.

$123 \mathrm{McF}$ adden E, Denison D, Waller J, Assonfi B, Peacock A, Sopwith T. Direct recordings of the temperatures in the tracheobronchial tree in normal man. F Clin Invest 1982; 69:700-5.

124 Craighead J, Meier M, Cooley M. Pulmonary infection due to rhinovirus type 13. $N$ Engl $\mathcal{F}$ Med 1969;281: 1403-4.

125 Heras J, Swanson V. Sudden death of an infant with rhinovirus infection complicating bronchial asthma: a case report. Pediatr Pathol 1983;1:319-23.
126 Horn MEC, Reed SA, Taylor P. Role of viruses and bacteria in acute wheezy bronchitis in childhood: a stud of sputum. Arch Dis Child 1979;54:587-92.

127 Halperin S, Eggleston P, Hendley J, Suratt P, Hendley J, Grocschel D, et al. Exacerbations of asthma in adults during experimental rhinovirus infection. Am Rev Respir Dis 1985;132:976-80.

128 Gern J, Galagan D, Jariour N, Kelly E, Busse W. Detection of rhinovirus 16 (RV16) in the lower airway of experimentally-infected subjects. 7 Allergy Clin Immunol perimentally-inf

129 Bardin P, Johnston S, Sanderson G, Robinson S, Pickett $\mathrm{M}$, Fraenkel D, et al. Detection of rhinovirus infection of the nasal mucosa by oligonucleotide in situ hybridisation. Am f Respir Cell Mol Biol 1994;10:207-13. 